\title{
Impact of Food Adulteration on Consumer Perception and Brand Image of Kanwal Foods \& Spices Pvt. Ltd.
}

\author{
Ifra Fayaz Zaroo \\ Student of Integrated MBA, University of Kashmir, Jammu \& Kashmir, India.
}

CITATION: Zaroo, Ifra Fayaz (2019), "Impact of Food Adulteration on Consumer Perception and Brand Image of Kanwal Foods \& Spices Pvt. Ltd.", MERC Global's International Journal of Management, Vol. 7, Issue 3, pp. 234-237.

ARTICLE HISTORY: Submitted: February 20, 2019, Revision received: April 10, 2019, Accepted: April 22, 2019

ARTICLE TYPE: Research paper

\begin{abstract}
Consumers play an important role in the health of the economy. As consumers, the decisions we make apropos to various products for consumption affect the demand for those products. Kanwal, a household name for packaged spices and food products, started with a modest beginning way back in 1970 to provide quality food products to people of Jammu and Kashmir who were at the receiving end of "sub-standard" food products which mostly came from Punjab, especially spices. This paper discusses how a minor challenge that might have aroused because of political and social reasons could have been averted by paying an affordable amount turned into a positive thing for Kashmir's leading brand Kanwal. The controversy did not change the opinion of consumers much, the survey showed $77.3 \%$ of people still considered Kanwal a healthy brand beside all the adulteration and controversy.
\end{abstract}

KEYWORDS: Consumer perception, Repercussion, Food adulteration, Kanwal Foods.

\section{BIBLIOGRAPHY}

1. Adhikari, Sandesh (2018), "Food Adulteration, Types of Food Adulteration and Mitigation Measures", Public Health Notes, available at: https://www.publichealthnotes.com/food-adulteration-types-of-foodadulteration-and-mitigation-measures/.

2. Dhyani, A. and Saklani, A. (1994), "To assess awareness of consumers towards consumer protection laws", International Journal of Market, Vol. 23, pp. 9-12.

3. Gurusamy (2013), "Food cos fined Rs. 10 Cr for adulteration - Tribune News Service", Food Safety Update, available at: https://foodsafetyupdate.wordpress.com/2013/12/26/food-cos-fined-rs-10-cr-foradulteration-tribune-news-service/.

4. Kashmir Times (2014), "After Khyber, Kanwal Spices Gets Relief From SC", 1 November, available at: http://www.kashmirtimes.in/newsdet.aspx?q=28197.

5. Kotler, P. (1990), Marketing Management, Prentice Hall of India Pvt. Ltd., New Delhi, India.

6. Mudambi, R. and Rajgopal, M. (1985), Fundamentals of Foods and Nutrition, Wiley Eastern Ltd., New Delhi, India.

7. Roday, S. (2002), Food Hygiene and Sanitation, Tata McGraw Hill Co. Ltd., New Delhi, India.

8. Zere, E. and McIntyre, D. (2003), "Inequities in under 5 child malnutrition in South Africa", International Journal of Equity Health, Vol. 45, pp. 20-26. 